\title{
BIMBINGAN DAN PELATIHAN PEMBUATAN BAKSO DAN NUGGET BAGI IBU-IBU DESA TORJUN SAMPANG MADURA
}

\author{
Siti Nurbaya', Heru Utomo², Bambang Suryanto3 \\ 123Politeknik Negeri Malang \\ 1Email Address: siti.nurbaya@polinema.ac.id, 2Email Address: \\ heru.utomo@polinema.ac.id,3Email Address: bambang.suryanto@polinema.ac.id
}

\begin{abstract}
Torjun village that located on the Sampang, Madura island was one of the village that very close to the beach. This village was also a fishing area because $95 \%$ of the population, especially men, lived by "majeng" (or as fishermen). Meanwhile, the wife of the fishermens was only became housewives. The problem that usually arises in fishermen's daily activities was the highly-needs for family life that wasn't inapropriate with the income level from fishing, so that they must seeking any opportunities that could improve their income. Therefore, they was also needs special skills that can increase income for fishermen's wives. From that problems, we will give a training in making meatballs and nuggets from fish. This activity also received a high enthusiasm from the participants. This enthusiasm was proven by the completeness of the 20 participants that were listened to the discussion. All of participants were active from the beginning until the end of the section. As the PKM groups, we were concluded that all participants were able to practice the results of the training by being able to made fish balls and fish nuggets that made from tuna and mackerel fish.
\end{abstract}

Keywords: Fish Meatballs, Nuggets Meatballs, Housewives of Torjun Village

\begin{abstract}
Abstrak
Desa Torjun Sampang merupakan salah satu desa yang dekat dengan pantai, desa ini merupakan daerah nelayan, 95\% penduduknya terutama laki-laki mencari nafkah dengan "majeng" yaitu melaut (sebagai nelayan). Sedangkan perempuannya rata-rata hanya menjadi ibu rumah tangga. Permasalahan yang kerap muncul pada keluarga nelayan adalah tingginya kebutuhan hidup keluarga yang tidak sebanding dengan penghasilan melaut sehingga kebutuhan dalam keluarga mereka dalam segi ekonomi harus dipenuhi. Oleh karena itu diperlukan keterampilan khusus yang dapat meningkatkan pendapatan bagi istri nelayan salah satunya adalah melalui pelatihan pembuatan bakso dan nugget dari ikan. Kegiatan ini mendapatkan antusiasme yang tinggi dari peserta. Antusiasme ini dibuktikan dengan kelengkapan peserta sejumlah 20 orang yang menyimak pembahasan dengan seksama dan aktif dari awal hingga akhir kegiatan. Kami sebagai tim pelaksana PKM menyimpulkan bahwa seluruh peserta mampu mempraktekkan hasil dari pelatihan tersebut dengan mampu membuat bakso ikan dan nugget ikan berbahan dasar ikan tongkol dan ikan tengiri.
\end{abstract}

Kata Kunci: Bakso Ikan, Nugget Ikan, Ibu- Ibu Desa Torjun 


\section{PENDAHULUAN}

Desa Torjun Sampang merupakan salah satu desa yang dekat dengan pantai, desa ini merupakan daerah nelayan, 95\% penduduknya terutama laki-laki mencari nafkah dengan "majeng" yaitu melaut (sebagai nelayan). Sedangkan perempuannya rata-rata hanya menjadi ibu rumah tangga. Kadang-kadang para istri hanya membantu suaminya jika pulang dari majeng, memilah ikan tangkapan, yang diperoleh pada saat melaut. Ibu-ibu istri nelayan desa Torjun, aktivitas kesehariannya yaitu mengurus rumah tangga, mereka tidak mempunyai pekerjaan dan penghasilan tetap. Mereka memiliki waktu luang tetapi tidak digunakan semaksimal mungkin untuk melakukan kegiatan yang bermanfaat. Oleh karena itu diperlukan suatu aktivitas yang berguna yaitu pendidikan non formal/ketrampilan berbentuk bimbingan dan pelatihan untuk menghasilkan sesuatu, ilmu yang mempunyai nilai guna sehingga di waktu yang akan datang mereka mempunyai usaha yang dapat menghasilkan uang. Makruf et al., (2016) mengemukakan bahwa dalam upaya peningkatan ekonomi rumah tangga nelayan, dapat dilakukan dengan berbagai cara atara lain sebagai berikut:

1. Pemanfaatkan waktu luang rumah tangga nelayan skala kecil dengan pengembangan usaha off-fishing merupakan alternatif untuk peningkatan ekonomi rumah tangga.

2. Peningkatan teknologi usaha offfishing yang dilakukan oleh rumah tangga nelayan skala kecil akan terwujud dengan pemberian pelatihan teknologi yang disertai dengan bantuan sarana yang diperlukan serta pembinaan dan pendampingan secara berkelanjutan.

3. Pembinaan dan pendampingan secara profesional sangat diperlukan oleh pelaku usaha off-fishing, mengingat sumberdaya yang dimiliki sangat terbatas.

4. Usaha off-fishing mempunyai peluang untuk dikembangkan karena dapat memanfaatkan bahan baku lokal serta menciptakan nilai tambah (value added) hasil perikanan.

5. Pemberian bantuan modal merupakan faktor penting untuk meningkatkan kapasitas dan mutu usaha off-fishing yang dilakukan oleh rumah tangga nelayan skala kecil, mengingat terbatasnya modal yang dimiliki.

Permasalahan yang kerap muncul pada keluarga nelayan adalah tingginya kebutuhan hidup keluarga yang tidak sebanding dengan penghasilan melaut sehingga kebutuhan dalam keluarga mereka dalam segi ekonomi harus 
dipenuhi. Oleh sebab itu diperlukan cara agar kebutuhan keluarga terpenuhi, mereka harus menambah penghasilan. Bimbingan dan pelatihan merupakan salah satu cara untuk memberikan ilmu pengetahuan dan ketrampilan bagi Ibuibu istri nelayan dalam usaha memenuhi kebutuhan dan menambah penghasilannya.

$$
\text { Utomo et al., (2011) }
$$
mengemukakan bahwa pengolahan ikan perlu dilakukan untuk lebih meningkatkan nilai komersial ikan dan memperpanjang umur simpan. Berbagai teknologi pengolahan produk ikan telah banyak dilakukan, antara lain pembuatan nuggets, berbagai jenis sosis, abon maupun bakso; namun pengolahan ikan yang relatif paling sederhana, murah, tidak membutuhkan bahan-bahan kimia tambahan dan mudah dilakukan oleh rumah tangga adalah bakso. Bakso juga merupakan jenis makanan yang sudah umum dikenal baik dikota bahkan di pelosok-pelosok pedesaan, terjangkau oleh berbagai kalangan ekonomi dan digemari oleh berbagai lapisan usia; berbeda dengan nuggets dan sosis yang selama ini lebih dikenal sebagai produk pangan untuk kalangan menengah keatas. Berdasarkan pemaparan latar belakang diatas, maka dapat dijelaskan permasalahan mitra antara lain:

1. Ibu-ibu istri nelayan desa Torjun, belum bisa menggunakan waktu luang yang ada untuk hal-hal yang produktif.

2. Ibu-ibu istri nelayan, perlu diberikan modal ilmu, ketrampilan untuk membuka usaha rumahan, agar dapat memenuhi kebutuhan hidupnya sehari-hari.

Kami selaku Pelaksana dalam kegiatan Pengabdian Kepada Masyarakat (PkM) dalam menjawab permasalahan di masyarakat nelayan Desa Torjun, Madura menawarkan solusi dengan mengolah hasil tangkapan ikan menjadi produk yang tahan lama dan memiliki nilai keekonomian yang tinggi. Produk tersebut adalah bakso dan nugget ikan. Target luaran dalam kegiatan ini adalah ibu-ibu Desa Torjun diharapkan mampu untuk mengolah ikan hasil tangkapan (ikan tengiri dan ikan tongkol) menjadi bakso dan nugget. Selain itu, diharapkan pula kegiatan PKM ini memiliki target luaran berupa artikel hasil PkM yang akan dipublikasikan pada jurnal BerISSN/ISBN.

\section{METODE DAN PELAKSANAAN}

\section{Metode}

Metode yang dilakukan oleh pelaksana kegiatan PKM antara lain: (1) transfer pengetahuan yang diberikan dengan metode penyampaian materi yang sesuai dengan memberikan contohcontoh dalam bentuk nyata, misalnya bahan-bahan dasar yang digunakan 
dalam membuat berbagai macam bakso dan nugget ; (2) Diskusi dan Tanya Jawab yang dilaksanakan untuk memberi kesempatan kepada khalayak sasaran dalam mengetahui dan memahami tentang materi yang diberikan atau disampaikan serta membangun komunikasi dan hubungan yang lebih baik antar pelaksana PkM dan khalayak sasaran. Dalam penyampaian materi, Pelaksana PkM terlibat secara langsung membantu Ibu-ibu dalam menyampaikan materi, dengan menggunakan bahasa Indonesia,dan diselingi bahasa yang mereka gunakan sehari-hari serta menjaga situasi tetap formal tapi santai, bagaimana mempengaruhi khalayak sasaran namun tidak terlihat dan terkesan menggurui mereka.

\section{Pelaksanaan Kegiatan}

Kegiatan PKM tahun 2020 ini dilaksanakan di salah satu rumah warga di Desa Torjun, Kecamatan Torjun, Kabupaten Sampang Madura. Kegiatan ini diikuti oleh 20 orang ibu-ibu. Kegiatan ini dilaksanakan pada tanggal 2 Juni 2020 dari pukul 08.00 sampai selesai. Sebelum kegiatan PKM dilaksanakan, kami selaku pelaksana kegiatan PKM melakukan screening terhadap suhu badan dari masingmasing peserta. Setelah semua peserta selesai dilakukan pengecekan suhu badan, maka selanjutnya pelaksana kegiatan PKM melakukan sterilisasi dengan memberikan hand sanitizer kepada setiap peserta agar semua peserta berada dalam keadaan bersih. Kegiatan PKM ini diawali dengan pemberian uraian singkat mengenai pentingnya mempunyai tambahan penghasilan dengan mengolah kembali ikan hasil tangkapan nelayan yang belum laku terjual. Setelah pemberian uraian selesai maka kegiatan PKM dilanjutkan dengan pembuatan bakso dan nugget dari ikan.

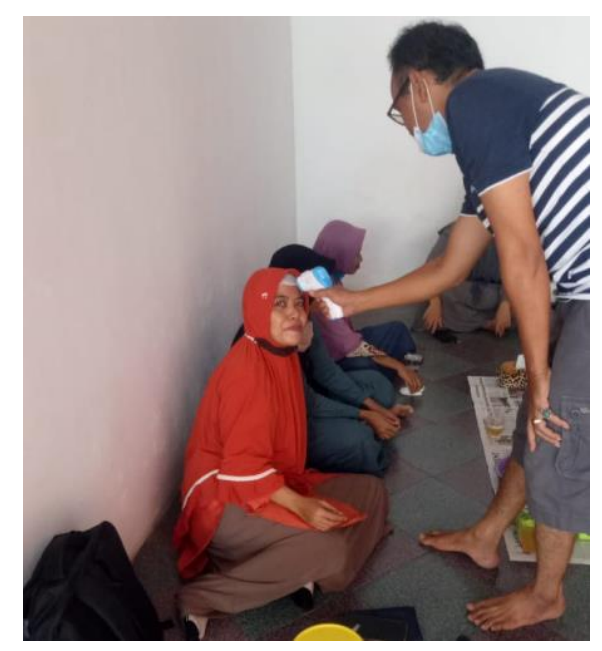

Gambar 1. Pengecekan Suhu Badan Sumber: Dokumentasi PKM 2020

\section{HASIL DAN PEMBAHASAN}

\section{Proses Pembuatan Bakso}

a. Ikan-ikan yang berukuran besar, daging dipisahkan dahulu dari tulang utamanya dengan cara dibuat filet. Pembuatan filet ikan dapat dilakukan sebagai berikut; Ikan diletakkan dengan posisi miring. Daging pada 
pangkal insang dipotong sampai ke tulang menggunakan pisau khusus. Kemudian daging ikan disayat ke arah ekor sampai daging terlepas dari tulang. Selanjutnya ikan dibalik, dan daging disayat dari ekor ke arah kepala. Pisau ditekan agak menempel tulang, supaya daging tidak banyak tertinggal pada tulang.

b. Setelah daging terpisah dari tulang, kulit juga dipisahkan sehingga diperoleh daging bebas tulang dan kulit. Tidak semua jenis ikan mudah dikuliti. Beberapa jenis ikan ada yang sukar dikuliti, dapat dilakukan penghilangan kulitnya menggunakan meat separator.

c. Filet ikan lalu dicuci bersih dengan air mengalir atau dicuci dengan bak untuk menghilangkan kotoran dan sisa-sisa darah. Bak pencucian lebih cocok menggunakan fiber glass, karena mudah dibersihkan, dipindahkan dan dikeringkan. Air pencucian harus sering diganti, tidak boleh sampai kotor dan keruh. Selama proses pembuatan filet dan pencucian ikan harus selalu ditambahkan es secukupnya untuk menghambat proses kemunduran mutu ikan

d. Fillet yang telah berbentuk dipotong potong kecil, kemudian dilakukan pelumatan/ penggilingan. Tujuan proses penggilingan/pelumatan daging/ikan adalah untuk meperkecil ukuran daging menjadi partikelpartikel yang ukurannya homogen. Sehingga bila dicampur dengan bumbu-bumbu, maka bumbu tersebut akan tercapur rata dengan adonan.

e. Pada tahapan ini terjadi proses emulsifikasi yaitu pencampuran antara daging yang telah dihaluskan dengan tepung tapioka/tepung aren/tepung sagu, dan bumbubumbu. Jumlah tepung yang ditambahkan sekitar 10-40\% dari berat daging. Bumbu-bumbu yang berupa merica, bawang putih, dan bawang merah goreng ditambahkan dengan jumlah sesuai selera, sedangkan garam biasanya ditambahkan dengan jumlah 2,5\% dari berat daging.

f. Setelah proses emulsifikasi selesai dengan ditandai dengan bahan-bahan berbentuk adonan, kemudian dilakukan pencetakan menjadi bolabola bakso yang siap untuk direbus. Pembentukan adonan menjadi bolabola bakso dapat mempergunakan tangan dibantu dengan sendok

g. Cara membentuk bola bakso dengan menggunakan tangan, yaitu dengan mengambil segenggam adonan lalu diremas/dikepalkan atau ditekan sampai adonan keluar diantara ibu jari dan telunjuk, sehingga 
membentuk bulatan dan diambil dengan sendok langsung diambil dan dimasukan ke dalam air panas.

h. Perebusan bola bakso dilakukan selama \pm 15 menit. Apabila bola bakso mengapung di permukaan air, berarti sudah matang, lalu diangkat dan ditiriskan. Agar bakso dapat tahan lama maka bakso harus dikemas dalam kantong plastik dan disimpan dalam suhu dingin (suhu $4^{\circ}-5^{\circ} \mathrm{C}$ ).

\section{Proses Pembuatan Nugget}

Bahan dasar yang digunakan untuk membuat nugget ikan (fish nugget) adalah ikan tongkol atau ikan yang segar. Pembuatan filet ikan dilakukan dengan cara sebagai berikut :
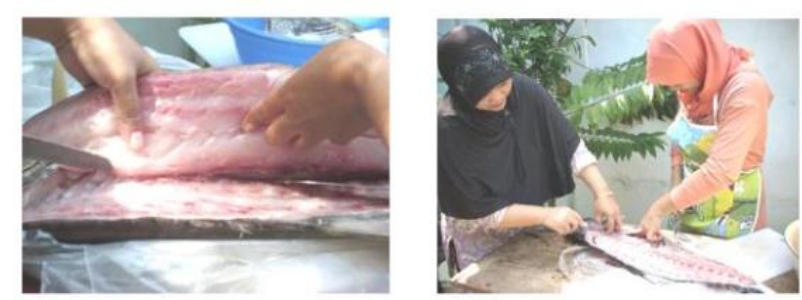

Gambar 2. Pembuatan fillet ikan

Sumber. Dokumentasi Pelaksana PKM 2020

1. Ikan disiangi terlebih dahulu, supaya isi perut tidak menjadi sumber bakteri dan enzim yang dapat merusak daging ikan. Penyiangan dilakukan dengan hati-hati agar isi perut tidak mencemari daging. Setelah disiangi ikan dicuci bersih.

2. Ikan diletakkan dengan posisi miring. Daging pada pangkal insang dipotong sampai ke tulang menggunakan pisau khusus. Kemudian daging ikan disayat ke arah ekor sampai daging terlepas dari tulang. Selanjutnya ikan dibalik, dan daging disayat dari ekor ke arah kepala. Pisau ditekan agak menempel tulang, supaya daging tidak banyak tertinggal pada tulang.

3. Setelah daging terpisah dari tulang, kulit juga dipisahkan sehingga diperoleh daging bebas tulang dan kulit. Beberapa jenis ikan ada yang sukar dikuliti, sehingga dapat dilakukan penghilangan kulit dengan meat separator.

4. Filet ikan dicuci bersih dengan air mengalir atau dicuci dengan bak untuk menghilangkan kotoran dan sisa-sisa darah. Bak pencucian lebih cocok menggunakan fiber glass, karena mudah dibersihkan, dipindahkan dan dikeringkan. Air pencucian harus sering diganti, tidak boleh sampai kotor dan keruh. Selama proses pembuatan fillet dan pencucian ikan harus selalu ditambahkan es secukupnya untuk menghambat proses kemunduran mutu ikan.

5. Siapkan Tepung terigu, tepung maizena, bumbu dan baking powder dibuat adonan cair (butter) dengan air es untuk merekatkan bread crumb pada nugget.

6. Bawang bombay diiris dan digoreng dengan margarin/minyak goreng 
sampai setengah matang bertujuan untuk memperoleh aroma yang lebih tajam kemudian disisihkan.

7. Bumbu-bumbu seperti garam, merica, bawang putih, bawang merah ditumbuk sampai halus kemudian sisihkan. Bumbu tersebut di tambah dengan tujuan untuk menambah cita rasa, supaya nugget lebih gurih. Telur digunakan untuk campuran adonan nugget.

8. Fillet yang telah bersih dilumatkan menggunakan alat penggiling daging atau silent cutter / food prosessor sehingga diperoleh daging lumat. Jika daging lumat ini masih mengandung serat dan duri, dipisahkan terlebih dahulu.

9. Daging lumat tersebut digiling dengan garam dan bumbu hingga rata. Selanjutnya ditambahkan tepung tapioka sedikit demi sedikit sambil diaduk, sampai diperoleh adonan yang homogen. Pada saat pembentukan adonan nugget ikan ditambahkan es batu sekitar 15\% 20\%. Es ini berfungsi untuk mempertahankan suhu rendah dan menambah air ke dalam adonan

10. Adonan yang telah homogen kemudian di masukkan ke dalam cetakan

(loyang) yang telah di olesi margarin atau dialasi dengan plastik dengan tujuan supaya adonan tidak lengket setelah dikukus.

11. Pengukusan di lakukan dengan menggunakan dandang selama $\pm 20-$ 30 menit sampai matang.

12. Adonan yang telah dikukus dan matang, kemudian didinginkan, supaya pengirisan lebih mudah dan bentuk irisannya tidak hancur, kemudian diiris (dibentuk) sesuai selera dengan menggunakan pisau stainles steel yang tajam.

13. Adonan yang telah didinginkan dan diiris tadi, dicelupkan ke dalam butter supaya tepung roti/bread crumb yang akan dibalurkan dapat menempel dan irisan nugget tidak hancur pada saat di goreng.

Irisan nugget yang telah dilapisi tepung roti/bread crumb kemudian di goreng dalam minyak goreng yang panas. Setelah matang (warnanya kekuningkuningan) lalu diangkat dan ditiriskan. Apabila telah dingin baru kemudian di kemas dalam kantong plastik. Dapat juga setelah setengah matang, nugget di goreng kemudian didinginkan lalu di kemas dalam kantong plastik dan dapat disimpan di dalam lemasi es (freezer), dengan tujuan agar penyimpanan lebih tahan lama 


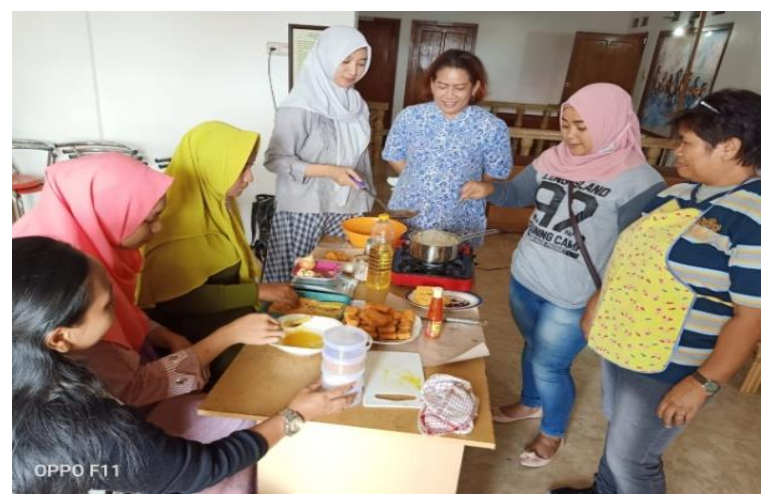

Gambar 3. Proses Penggorengan Nugget Ikan

Sumber: Dokumentasi Pelaksana PKM 2020

\section{Luaran yang Dicapai}

Berdasarkan kegiatan pengabdian yang telah dilakukan, luaran yang telah dicapai adalah Ibu-Ibu Desa Torjun, Kabupaten Sampang Madura telah mampu dan kapabel dalam mengolah ikan tongkol dan ikan tengiri menjadi produk olahan bakso ikan dan nugget ikan dengan proses yang higinis dan mengikuti standar markets. Berikut adalah gambar hasil olahan nugget dan bakso ikan yang dipoduksi oleh Ibu-Ibu Desa Torjun Sampang Madura:

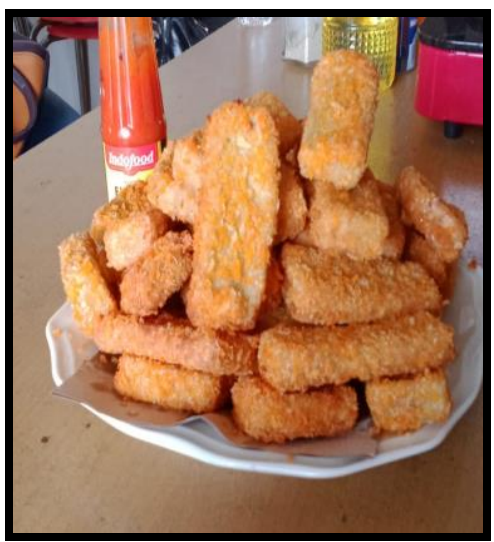

Gambar 4. Olahan Nugget Ikan

Sumber: Dokumentasi Pelaksana PKM 2020

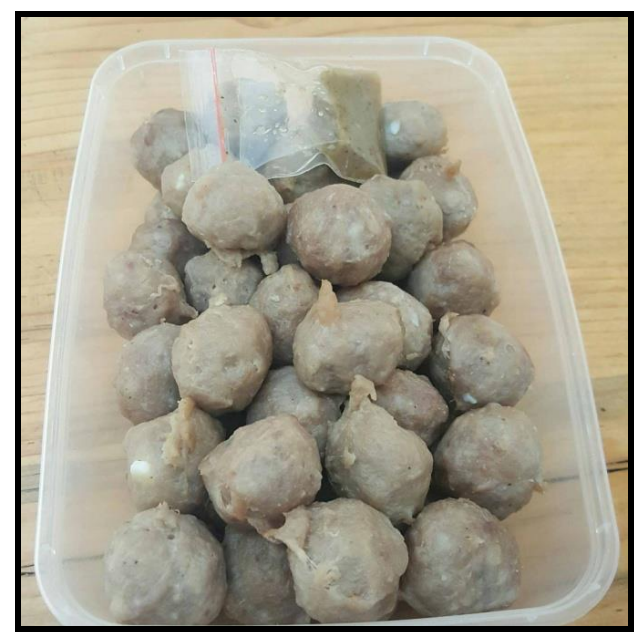

Gambar 5. Olahan Bakso Ikan

Sumber: Dokumentasi Pelaksana PKM, 2020

\section{PENUTUP}

\section{Simpulan}

Kegiatan Pengabdian Kepada Masyarakat (PKM) yang bertajuk Bimbingan Dan Pelatihan Pembuatan Bakso Dan Nugget Bagi Ibu-Ibu Desa Torjun Sampang telah dilaksanakan dengan baik. Kegiatan ini mendapatkan antusiasme yang tinggi dari peserta. Antusiasme ini dibuktikan dengan kelengkapan peserta sejumlah 20 orang yang menyimak pembahasan dengan seksama dan aktif dari awal hingga akhir kegiatan. Kami sebagai tim pelaksana PKM menyimpulkan bahwa seluruh peserta mampu mempraktekkan hasil dari pelatihan tersebut dengan mampu membuat bakso ikan

\section{Saran}

Setelah melakukan kegiatan pengabdian ini, kami selaku Tim Pengabdian Kepada Masyarakat (PkM) Jurusan Administrasi 
Niaga Politeknik Negeri Malang memberikan saran kepada Ibu-Ibu Desa Torjun agar memperhatikan beberapa hal berikut ini:

a) Para ibu-ibu dapat menyimpan daging ikan dalam freezer. Daging yang membeku dapat membuat daging ikan menjadi lebih berserat dan kesat.

b) Untuk membuat variasi jenis bakso dapat ditambah dengan topping yang cukup viral di masyarakat seperti keju dan cabai merah.

c) Untuk membuat variasi jenis nugget dapat ditambah dengan topping seperti keju dan saos american risoles.

\section{Ucapan Terima Kasih}

Kami selaku Pelaksana Kegiatan PKM Jurusan Administrasi Bisnis Politeknik Negeri Malang mengucapkan terima kasih kepada Perangkat Desa Torjun yang telah memfasilitasi kami dalam pelaksanaan kegiatan ini, serta kami juga mengucapkan terima kasih kepada Ibu Tika sebagai pemateri dalam kegiatan ini.

\section{DAFTAR PUSTAKA}

Makruf, A., Priyawan, S., \& Ujianto. (2016). Analisis Pengaruh Moral Ekonomi Dan Derajat Kewirausahaan Terhadap Perilaku Ekonomi Rumah Tangga Nelayan Dan Implikasinya Terhadap Kesejahteraan Ekonomi Rumah Tangga Nelayan Kabupaten Sampang Jawa Timur. Jurnal Doktor Ekonomi, 1(1), 43-58. https://doi.org/10.3969/j.issn.16727851.2016.10.005

Utomo, D., Wahyuni, R., \& Wiyono, R. (2011). PEMANFAATAN IKAN GABUS (Ophiocephalus striatus) MENJADI BAKSO DALAM RANGKA PERBAIKAN GIZI MASYARAKAT DAN UPAYA MENINGKATKAN NILAI EKONOMISNYA. Teknologi Pangan : Media Informasi Dan Komunikasi Ilmiah Teknologi Pertanian, 1(1), 38-55. https://doi.org/10.35891/tp.v1i1.4 76 